\title{
Individualized Cutoff Value of the Serum Carcinoembryonic Antigen Level According to TNM Stage in Colorectal Cancer
}

\author{
Byung-Kwon Ahn \\ Department of Surgery, Kosin University College of Medicine, Busan, Korea
}

See Article on Page 106-114

Serum carcinoembryonic antigen (CEA) is the most widely used tumor marker for the management of colorectal cancer. The preoperative serum CEA level has been reported to be one of prognostic parameters for the recurrence of colorectal cancers $[1,2]$. Postoperative monitoring of the serum CEA level has been commonly used in the follow-up for colorectal cancers [3]. However, whether the preoperative serum CEA level has a prognostic significance according to individual stages in patients with colorectal cancer is controversial [4-7]. Harrison et al. [6] analyzed a large cohort of node-negative colon cancer patients (T1-4, N0, M0) to determine prognostic factors. The study demonstrated that the preoperative serum CEA elevation $(>5 \mathrm{ng} / \mathrm{mL}$ ) had a poor prognostic value in node-negative patients (T1-4, N0, M0). Another study showed that $5 \mathrm{ng} / \mathrm{mL}$, as cutoff value for serum CEA, had no significant prognostic value within the different Dukes' stages and had borderline prognostic value in the Dukes' C stage [7]. Those trials to identify the prognostic value of serum CEA elevation within individual stages have some limitations. The biochemical characters of serum CEA are not well known. For those trials, hypotheses are necessary. Serum CEA has other biochemical characters, but not as a marker to predict increasing size of tumor or metastasis to lymph nodes. Serum CEA might be a sensitive marker, represents size and metastasis.

Few studies have reported optimal cutoff values for serum CEA levels in patients with colorectal cancer. Reiter et al. [8] reported the results of a multivariate analysis of the prognostic value of serum CEA level in colorectal cancer. For preoperative serum CEA

Correspondence to: Byung-Kwon Ahn, M.D.

Department of Surgery, Kosin University College of Medicine,

262 Gamcheon-ro, Seo-gu, Busan 602-702, Korea

Tel: +82-51-990-6462, Fax: +82-51-246-6093

E-mail:gsabk@hotmail.com

(C) 2013 The Korean Society of Coloproctology

This is an open-access article distributed under the terms of the Creative Commons Attribution NonCommercial License (http://creativecommons.org/licenses/by-nc/3.0) which permits unrestricted noncommercial use, distribution, and reproduction in any medium, provided the original work is properly cited. levels of $\geq 4 \mathrm{ng} / \mathrm{mL}$ vs. $<4 \mathrm{ng} / \mathrm{mL}$, the relative risk was $1.4(\mathrm{P}<0.07)$. The 2-year survival rates in the groups of patients with preoperative serum CEA levels $>4 \mathrm{ng} / \mathrm{mL}$ and $<4 \mathrm{ng} / \mathrm{mL}$ were $16 \%$ and $38 \%$, respectively, for patients with Dukes' stage D cancer, $73 \%$ and $91 \%$ for patients with Duke's stage B/C cancer, and $100 \%$ and 98\% for patients with Dukes' stage A cancer. Also, Takagawa et al. [2] reported that the relapse-free survival was significantly different in patients with stage II and III according to preoperative CEA level ( $>10 \mathrm{ng} / \mathrm{mL}$ vs. $<10 \mathrm{ng} / \mathrm{mL})$. However, in patients with stage I, there was no significant difference in relapse-free survival. Park et al. [9] divided patients with colorectal cancer into four subgroups by using serum CEA cutoff values of 3,6 , and $17 \mathrm{ng} / \mathrm{mL}$. Their 5 -year disease free survival rates were $85.3 \%(<3.0 \mathrm{ng} / \mathrm{mL}), 70.0 \%$ $(3-6 \mathrm{ng} / \mathrm{mL}), 64.2 \%(6-17 \mathrm{ng} / \mathrm{mL})$, and $55.2 \%(>17 \mathrm{ng} / \mathrm{mL})(\mathrm{P}<$ $0.001)$. According to stage, a significant difference in survival was observed only in patients with stage III tumors $(\mathrm{P}=0.007)$.

In this study, the authors tried to determine the individual optimal cutoff value of CEA according to TNM stage [10]. The conventional cutoff value of CEA $(5 \mathrm{ng} / \mathrm{mL})$ has no significant prognostic value in stage T1-2, N0 and stage T1-4, N2. Optimal cutoff values from the receiver operating characteristic curve were 7.4, 5.5 and $4.5 \mathrm{ng} / \mathrm{mL}$ for TNM stages I, II and III, respectively. Those for stages $\mathrm{N} 0, \mathrm{~N} 1$ and $\mathrm{N} 2$ were $5.5,4.8$ and $3.5 \mathrm{ng} / \mathrm{mL}$, respectively. The 5 -year disease free survivals were significantly different with these cutoff values for each TNM and N stages. However, one has to consider that a sub-normal CEA level may be a cutoff value that can be used as a prognostic marker.

\section{CONFLICT OF INTEREST}

No potential conflict of interest relevant to this article was reported.

\section{REFERENCES}

1. Park YA, Lee KY, Kim NK, Baik SH, Sohn SK, Cho CW. Prognostic effect of perioperative change of serum carcinoembryonic antigen level: a useful tool for detection of systemic recurrence in rectal cancer. Ann Surg Oncol 2006;13:645-50.

2. Takagawa R, Fujii S, Ohta M, Nagano Y, Kunisaki C, Yamagishi S, 


\section{Coloproctology Byung-Kwon Ann}

et al. Preoperative serum carcinoembryonic antigen level as a predictive factor of recurrence after curative resection of colorectal cancer. Ann Surg Oncol 2008;15:3433-9.

3. Huh JW, Oh BR, Kim HR, Kim YJ. Preoperative carcinoembryonic antigen level as an independent prognostic factor in potentially curative colon cancer. J Surg Oncol 2010;101:396-400.

4. Watine J, Miédougé M, Friedberg B. Carcinoembryonic antigen as an independent prognostic factor of recurrence and survival in patients resected for colorectal liver metastases: a systematic review. Dis Colon Rectum 2001;44:1791-9.

5. Wiratkapun S, Kraemer M, Seow-Choen F, Ho YH, Eu KW. High preoperative serum carcinoembryonic antigen predicts metastatic recurrence in potentially curative colonic cancer: results of a fiveyear study. Dis Colon Rectum 2001;44:231-5.

6. Harrison LE, Guillem JG, Paty P, Cohen AM. Preoperative carcinoembryonic antigen predicts outcomes in node-negative colon cancer patients: a multivariate analysis of 572 patients. J Am Coll Surg 1997;185:55-9.

7. Carpelan-Holmström M, Haglund C, Lundin J, Järvinen H, Roberts P. Pre-operative serum levels of CA 242 and CEA predict outcome in colorectal cancer. Eur J Cancer 1996;32A:1156-61.

8. Reiter W, Stieber P, Reuter C, Nagel D, Lau-Werner U, Lamerz R. Multivariate analysis of the prognostic value of CEA and CA 19-9 serum levels in colorectal cancer. Anticancer Res 2000;20(6D): 5195-8.

9. Park IJ, Kim HC, Yu CS, Yoo JH, Kim JC. Cutoff values of preoperative s-CEA levels for predicting survivals after curative resection of colorectal cancer. J Korean Med Sci 2005;20:624-7.

10. Jeon BG, Shin R, Chung JK, Jung IM, Heo SC. Individualized Cutoff Value of the Preoperative Carcinoembryonic Antigen Level Necessary for Optimal Use as a Prognostic Marker. Ann Coloproctol 2013;29:106-14. 